\title{
Effects of Dietary Rapeseed Meal on Growth Performance, Carcass Traits, Serum Parameters, and Intestinal Development of Geese
}

\author{
Zhenming Fu ${ }^{1}{ }^{(}$, Guoqiang Su ${ }^{1}$, Haiming Yang ${ }^{1, *}$, Qingyu Sun ${ }^{1}$, Tao Zhong ${ }^{1}$ and Zhiyue Wang ${ }^{1,2}{ }^{\mathbb{D}}$ \\ 1 College of Animal Science and Technology, Yangzhou University, Yangzhou 225009, China; \\ dyjiajiehuagong@163.com (Z.F.); sgqyzu@163.com (G.S.); sqy203610@163.com (Q.S.); \\ zhong19825305405@163.com (T.Z.); dkwzy@263.net (Z.W.) \\ 2 Joint International Research Laboratory of Agriculture and Agri-Product Safety of Ministry of Education of \\ China, Yangzhou University, Yangzhou 225009, China \\ * Correspondence: yhmdlp@163.com
}

check for updates

Citation: Fu, Z.; Su, G.; Yang, H.; Sun, Q.; Zhong, T.; Wang, Z. Effects of Dietary Rapeseed Meal on Growth Performance, Carcass Traits, Serum Parameters, and Intestinal Development of Geese. Animals 2021, 11, 1488. https://doi.org/10.3390/ ani11061488

Academic Editors: Paweł Konieczka and Dorota Bederska-Łojewska

Received: 22 April 2021

Accepted: 16 May 2021

Published: 21 May 2021

Publisher's Note: MDPI stays neutral with regard to jurisdictional claims in published maps and institutional affiliations.

Copyright: (c) 2021 by the authors. Licensee MDPI, Basel, Switzerland. This article is an open access article distributed under the terms and conditions of the Creative Commons Attribution (CC BY) license (https:/ / creativecommons.org/licenses/by/ $4.0 /)$.
Simple Summary: The poultry industry faces challenges such as a shortage of protein feed and increased feed cost. Compared to soybean meal, rapeseed meal (RSM) is a cheaper protein source that can be used in poultry diets. China is both the largest RSM and geese producer in the world. Therefore, the active use of RSM for geese diets can contribute to the development of poultry production. We found that geese had a good adaptation to the diet containing $16 \%$ dietary RSM through the investigation.

\begin{abstract}
The use of inexpensive nonconventional feed materials, such as rapeseed meal (RSM), could help alleviate the shortage of feed materials in the poultry industry. This study was to investigate the effects of dietary double-low RSM on growth performance, carcass traits, serum parameters, and intestinal development of geese. A total of 270 healthy 35-day-old male Jiangnan White geese were randomly divided into five treatments, with six replicate pens of nine geese each. The geese were fed five isonitrogenous and isocaloric diets containing $0 \%, 4 \%, 8 \%, 12 \%$, and $16 \%$ RSM replacing dietary soybean meal for 35 days. At 35, 49, and 70 d, the BW and feed intake were recorded. All Samples were collected at $70 \mathrm{~d}$ of age. The results showed that dietary RSM up to $16 \%$ did not affect the BW, ADFI, ADG, and feed/gain ratio (F/G) during 35 to $49 \mathrm{~d}, 49$ to $70 \mathrm{~d}$, and 35 to $70 \mathrm{~d}$ periods $(p>0.05)$. At $70 \mathrm{~d}$, no difference was observed in carcass yield or serum biochemical parameters among groups $(p>0.05)$. Dietary $12 \%$ and $16 \%$ RSM significantly increased the concentration of serum GH compared with $0 \%, 4 \%, 8 \%$ groups $(p<0.01)$, but serum TSH, T3 and T4 were unaffected $(p>0.05)$. The relative weights of heart, liver, spleen, proventriculus, gizzard, and small intestine were similar among groups $(p>0.05)$. However, the geese fed dietary $16 \%$ RSM had greater bursa of Fabricius than geese in the $8 \%$ group $(p<0.05)$. Intestinal morphology was unaffected by treatments $(p>0.05)$. According to the findings, dietary RSM up to $16 \%$ can be used in geese diets without impact on production performance.
\end{abstract}

Keywords: rapeseed meal; geese; performance; carcass traits; serum parameters; intestinal development

\section{Introduction}

With the acceleration of the intensive geese breeding process in China, the geese industry directly competes with humans for major feed ingredients. The shortage of protein source feeds (e.g., soybean meal, SBM) required to formulate balanced geese ration increased annually, together with unit cost. Feed cost is a great expense accounting for about $70 \%$ of the total cost of geese production, of which the protein source represents a large part [1,2]. Thus, the discovery and utilization of more cost-effective alternatives that maintain normal growth performance and are preferably not used in human nutrition would promote geese production. 
Rapeseed meal (RSM), an oil-byproduct of high yield, is a cheaper alternative source of plant protein (crude protein, 35-42\%) for poultry diets compared with SBM [3]. It is also rich in vitamins (e.g., thiamine, choline, and folic acid), minerals (e.g., calcium, selenium, zinc, and iron), and avian limiting amino acid (e.g., methionine and lysine) [4,5]. However, the use of RSM in monogastric animal nutrition is mainly limited by the presence of glucosinolates (GLS) and its toxic metabolites of enzymatic hydrolysis [6]. The high concentration of GLS from excessive inclusion of dietary RSM could lead to hypothyroidism, abnormalities in digestive function, liver and kidney disorders, and impairment to body health [7-9]. In addition, anti-nutritional factors (ANFs) of RSM-including phytate, sinapine, condensed tannin (CT), and non-starch polysaccharides (NSP) - would decrease feed palatability, metabolism of feed nutrients [10], and thus growth performance [11].

Variety breeding and improvement, and seed processing by prepress solvent extraction or expeller-extraction method, contribute to reducing ANFs in RSM [12-14] and promoting RSM application in poultry feed. Qin et al. [9] found that meat ducks fed $6.6 \%$ of dietary RSM (7.75 $\mu \mathrm{mol} \mathrm{GLS/g)} \mathrm{exhibited} \mathrm{similar} \mathrm{organ} \mathrm{health} \mathrm{and} \mathrm{growth} \mathrm{rate} \mathrm{compared} \mathrm{with}$ diets based on corn-soybean meal from 15 to $35 \mathrm{~d}$ of age. Ahamed et al. [15] reported that canola meal can be used as up to $20 \%$ of the starter ( 1 to $28 \mathrm{~d}$ ) and finisher ( 29 to $42 \mathrm{~d}$ ) diets without having any adverse effects of broiler performance. Turkeys receiving $6 \%$ to $18 \%$ of dietary RSM maintained normal body weight after a 147-d feeding trial [16]. These suggested that moderate inclusion of low-GLS RSM could effectively substitute SBM in diets for the mentioned poultry. In contrast, the literary data on feeding values of RSM is scarce on geese. The deleterious effects of GLS partly depend on strain and age of birds and duration of feeding $[3,16]$. The physiological structure, digestive function, and growth period of geese are not the same as those of other poultry (e.g., broilers and turkeys) $[13,16,17]$ lead to a difference in tolerance of GLS and utilization efficiency of RSM-contained diets. Taken together, the basic hypothesis was that geese could utilize RSM, but with an uncertain amount. Therefore, this study aimed to investigate the effects of dietary levels of RSM as a replacement for SBM on growth performance, carcass traits, serum parameters, and intestinal development of geese.

\section{Materials and Methods}

\subsection{Experimental Design, Diets, and Management}

All procedures of this study were permitted by the Institutional Animal Care and Use Committee (IACUC) of the Yangzhou University Animal Experiments Ethics Committee, with the permit number: SYXK (Su) IACUC 2012-0029.

This experiment was conducted at the experimental ranch of Yangzhou University (Yangzhou, China) from June to August in 2020. A total of 270 healthy 35-day-old male Jiangnan White geese from the same hatch were obtained from a commercial hatchery (Jiangsu Lihua Animal Husbandry Co., Ltd., Changzhou, Jiangsu Province, China). According to a completely randomized design, the geese were all of similar body weight (BW) and randomly assigned to five dietary treatments, with six replicate pens per treatment and nine geese per pen. The control group was fed a basal corn-soybean meal (corn-SBM) diet, and the four experimental groups were fed diets containing $4 \%, 8 \%, 12 \%$, or $16 \%$ rapeseed meal (RSM) to replace the main protein source (SBM) in the control diet. These diets (mash form) were formulated to be isonitrogenous and isocaloric and meet or exceed the nutrient requirements of geese according to the NRC (1994) and prior research results from our laboratory $[1,2,18]$. Before diet formulation, all energy sources and protein-containing ingredients (i.e., corn, RSM, SBM, rice husk, and wheat bran) were analyzed in duplicate for dry matter (DM), crude protein $(\mathrm{CP})$, crude fat $(\mathrm{EE})$, crude fiber $(\mathrm{CF})$, calcium $(\mathrm{Ca})$, total phosphorus (TP), and ash according to the classical procedures set forth by the Association of Official Analytical Chemists (AOAC, 2006) [19]. Methionine (Met) and lysine (Lys) were determined using a Hitachi L-8900 automatic amino acid analyzer (Hitachi Ltd., Tokyo, Japan). The composition and nutrient levels of the experimental diets are listed in Table 1. The RSM sample was also analyzed for GLS content by an Agilent 1290 
Infinity-II high-performance liquid chromatography (HPLC) system (Agilent Technologies Inc., Santa Clara, CA, USA). The chemical composition of RSM is shown in Table 2. The mentioned feed ingredients were crushed and mixed using a hammer mill (2.5- $\mathrm{mm}$ screen, model SWFP66 $\times 60 \mathrm{C}$, Muyang, Yangzhou, China) before producing mash diets. During the 35-days experiment trial, all geese were reared in plastic wire-floor pens $(2.28 \times 1.24 \mathrm{~m})$ and exposed to natural light. The room temperature was approximately $28^{\circ} \mathrm{C}$ at the start and gradually decreased to approximately $23 \pm 2{ }^{\circ} \mathrm{C}$ (day and night) by temperature control equipment including fans and wet curtains during. Water and feed were provided ad libitum.

Table 1. Composition of rapeseed meal and soybean meal (air-dry basis) ${ }^{1}$.

\begin{tabular}{ccc}
\hline Items (\%) & Rapeseed Meal & Soybean Meal \\
\hline Moisture & 9.74 & 11.36 \\
Crude protein & 36.72 & 43.01 \\
Crude fat & 9.48 & 1.93 \\
Crude fiber & 7.08 & 6.48 \\
Calcium & 0.74 & 0.32 \\
Total phosphorus & 1.16 & 0.58 \\
Methionine & 0.71 & 0.58 \\
Lysine & 1.63 & 2.65 \\
Glucosinolate $(\mu \mathrm{mol} / \mathrm{g})$ & 12.29 & - \\
\hline
\end{tabular}

${ }^{1}$ Measured value. - Not measured.

Table 2. Composition and nutrient levels of experimental diets (air-dry basis) \%.

\begin{tabular}{|c|c|c|c|c|c|}
\hline \multirow{2}{*}{ Items } & \multicolumn{5}{|c|}{ Groups $^{1}$} \\
\hline & Control & $\mathrm{RSM}_{4}$ & $\mathrm{RSM}_{8}$ & $\mathrm{RSM}_{12}$ & $\mathrm{RSM}_{16}$ \\
\hline Corn & 58.33 & 59.02 & 59.71 & 60.40 & 61.09 \\
\hline Soybean meal (CP 43.01\%) & 25.40 & 22.36 & 19.31 & 16.27 & 13.22 \\
\hline Rapeseed meal (CP $36.72 \%$ ) & 0.00 & 4.00 & 8.00 & 12.00 & 16.00 \\
\hline Rice husk & 7.51 & 7.22 & 6.94 & 6.66 & 6.38 \\
\hline Wheat bran & 5.26 & 3.94 & 2.63 & 1.31 & 0.00 \\
\hline Limestone & 1.08 & 1.07 & 1.07 & 1.07 & 1.07 \\
\hline Dicalcium phosphate & 1.01 & 0.95 & 0.89 & 0.82 & 0.76 \\
\hline Salt & 0.30 & 0.30 & 0.30 & 0.30 & 0.30 \\
\hline DL-methionine & 0.13 & 0.12 & 0.11 & 0.10 & 0.09 \\
\hline L-lysine HCL & 0.00 & 0.02 & 0.05 & 0.07 & 0.09 \\
\hline Premix ${ }^{2}$ & 1.00 & 1.00 & 1.00 & 1.00 & 1.00 \\
\hline Total & 100.00 & 100.00 & 100.00 & 100.00 & 100.00 \\
\hline \multicolumn{6}{|l|}{ Nutrient level ${ }^{3}, \%$} \\
\hline $\mathrm{ME}(\mathrm{MJ} / \mathrm{kg})$ & 10.98 & 10.98 & 10.98 & 10.98 & 10.98 \\
\hline Crude protein & 16.54 & 16.54 & 16.54 & 16.54 & 16.54 \\
\hline Crude fiber & 6.22 & 6.22 & 6.22 & 6.22 & 6.22 \\
\hline Calcium & 0.84 & 0.84 & 0.84 & 0.84 & 0.84 \\
\hline Total phosphorus & 0.58 & 0.58 & 0.58 & 0.58 & 0.58 \\
\hline Available phosphorus & 0.44 & 0.43 & 0.42 & 0.41 & 0.40 \\
\hline Lysine & 0.84 & 0.84 & 0.84 & 0.84 & 0.84 \\
\hline Methionine & 0.38 & 0.38 & 0.38 & 0.38 & 0.38 \\
\hline Glucosinolate $(\mu \mathrm{mol} / \mathrm{g})$ & 0 & 0.49 & 0.98 & 1.47 & 1.97 \\
\hline
\end{tabular}

${ }^{1} \mathrm{RSM}$, rapeseed meal; ME, metabolizable energy; $\mathrm{RSM}_{4}, \mathrm{RSM}_{8}, \mathrm{RSM}_{12}$, and $\mathrm{RSM}_{16}$ indicate that the levels of isonitrogenous replacement of soybean meal with RSM added to the diets were $4 \%, 8 \%, 12 \%$, and $16 \%$, respectively. Control group was fed a corn-soybean meal basal diet. ${ }^{2}$ One kilogram of premix contained 1,200,000 IU retinol, 400,000 IU rachitasterol, $1800 \mathrm{IU}$ D-a-tocopherol, $150 \mathrm{mg}$ coagulation vitamin, $60 \mathrm{mg}$ thiamine, $600 \mathrm{mg}$ riboflavin, $200 \mathrm{mg}$ pyridoxine, $1 \mathrm{mg}$ cobalamin, $3 \mathrm{~g}$ nicotinic acid, $900 \mathrm{mg}$ pantothenic acid, $50 \mathrm{mg}$ folic acid, $4 \mathrm{mg}$ biotin, $35 \mathrm{mg}$ choline, $6 \mathrm{~g}$ Fe (ferrous sulfate), $1 \mathrm{~g} \mathrm{Cu}$ (copper sulfate), $9.5 \mathrm{~g} \mathrm{Mn}$ (manganese sulfate), $9 \mathrm{~g} \mathrm{Zn}$ (zinc sulfate), $50 \mathrm{mg}$ I (potassium iodide), and $30 \mathrm{mg}$ Se (sodium selenite). ${ }^{3}$ Calculated values. 


\subsection{Growth Performance}

The growth performance of geese was evaluated in terms of body weight (BW), average daily feed intake (ADFI), average daily gain (ADG), and the feed/gain ratio (F/G). The BW and feed intake of the birds in each pen were recorded at 35, 49, and 70 days of age. The ADG, ADFI, and F/G from 35 to 49,49 to 70 , and 35 to $70 \mathrm{~d}$ were calculated.

\subsection{Sample Collection and Measurement}

At $70 \mathrm{~d}$ of age, all geese were weighed individually after fasting for $6 \mathrm{~h}$. One goose of each pen with the mean weight of the pen was selected. Duplicate blood samples $(3 \mathrm{~mL} \times 2)$ were collected in sterile procoagulant tubes via wing venipuncture, centrifuged at $2000 \times \mathrm{g}$ for $10 \mathrm{~min}$ at $4{ }^{\circ} \mathrm{C}$ to harvest serum, and stored at $-20^{\circ} \mathrm{C}$ until analysis of serum parameters. Following this, the geese were exsanguinated by severing the jugular vein and carotid artery on one side of the neck. After bleeding and plucking (soaking in $70{ }^{\circ} \mathrm{C}$ water for approximately $2 \mathrm{~min}$ ), the weight was recorded. Then, the geese were eviscerated, and the semi-eviscerated carcass, eviscerated carcass, heart, liver, spleen, pancreas, bursa of Fabricius, proventriculus, empty gizzard, breast muscle, thigh muscle, and abdominal fat were weighed. The duodenum (from the gizzard outlet to the end of the pancreatic loop), jejunum (from the pancreatic loop to Meckel's diverticulum), and ileum (from Meckel's diverticulum to the ileo-caeco-colic junction) were isolated and weighed after evacuation. The percentages of the small intestine, carcass, semi-eviscerated carcass, and eviscerated carcass were calculated relative to the live BW, while the percentages of organs, breast muscle, thigh muscle, and abdominal fat were calculated relative to the eviscerated carcass weight.

\subsection{Serum Biochemical and Hormonal Parameters}

Serum concentrations of total protein (TP), albumin (ALB), glucose (GLU), triglyceride (TG), cholesterol (CHO), blood urea nitrogen (BUN), high-density lipoprotein (HDL), lowdensity lipoprotein $(\mathrm{LDL})$, calcium $(\mathrm{Ca})$, phosphorus $(\mathrm{P})$, glutamic pyruvic transaminase (ALT), glutamic-oxalacetic transaminase (AST), and alkaline phosphatase (AKP) were measured using a UniCel DxC 800 Synchron Clinical System autoanalyzer (Beckman Coulter Inc., Fullerton, Canada) with the respective detection kits (Shengkang Bio-tech Co., Ltd., Shaoxing, China). Serum TP was assayed by the biuret method. Serum ALB was assayed by the microplate assay method. Serum GLU was assayed by the GLU oxidase method. Serum BUN was assayed by the rate method. Serum TG and $\mathrm{CHO}$ were assayed by the enzyme-colorimetric method. Serum HDL and LDL were assayed by the direct method. Serum Ca and P were assayed by the ion electrode method. Serum ALT and AST were assayed by continuous monitoring method. Serum AKP was assayed by the enzymatic method. Serum growth hormone (GH), thyroid-stimulating hormone (TSH), triiodothyronine (T3), and tetraiodothyronine (T4) were determined by the ELISA method with the corresponding ELISA kits (Ybio Bio-tech Co., Ltd., Shanghai, China).

\subsection{Intestinal Morphology}

At $70 \mathrm{~d}$ of age, another goose of each pen with the mean weight of the pen was selected. After slaughtering by exsanguination, the duodenum, jejunum, and ileum were isolated. Sections (approximately $2 \mathrm{~cm}$ in length) from the midpoints of the duodenum, jejunum, and ileum were excised and flushed with phosphate-buffered saline (PBS) and immediately fixed by placing them in 10\% neutral-buffered formalin solution. Each fixed sample was embedded in wax, sectioned at a thickness of $5 \mu \mathrm{m}$, and stained with hematoxylin-eosin. For histological morphometric observations, the slides were analyzed by light microscopy, and digital images were captured (LY-WN-HP SUPER CCD, Chengdu, China). The height of villi and depth of crypts were measured for 10 villi at $\times 40$ magnification as described by Lu et al. (2011) [17]. 


\subsection{Statistical Analysis}

All the data were initially processed using Excel 2019 and analyzed using SPSS 20.0 (SPSS Inc., Chicago, IL, USA, 2011). One-way ANOVA with a post hoc test was used to elucidate significant differences. All the data were checked for normality. Duncan's test was used for multiple comparisons when a significant difference was detected. Differences were considered to be statistically significant at $p<0.05$, and $0.05<p<0.10$ was considered to be a trend towards significance. All the data were presented as the mean and standard error of the means (SEM).

\section{Results}

\subsection{Growth Performance}

BW, ADFI, ADG, and the F/G of geese fed graded levels of dietary RSM are shown in Table 3. Diets containing 4\%, $8 \%, 12 \%$, and $16 \%$ RSM did not affect the BW (40 d and $70 \mathrm{~d}$ of age) of geese compared with the control group ( $p>0.05$ ). During 35 to $49 \mathrm{~d}, 49$ to $70 \mathrm{~d}$, and 35 to $70 \mathrm{~d}$ of age, similar ADFI, ADG, and F/G of geese were observed among groups $(p>0.05)$.

Table 3. Effects of increasing dietary levels of rapeseed meal on the body weight (BW), average daily feed intake (ADFI), average daily gain $(\mathrm{ADG})$, and feed/gain ratio (F/G) of geese.

\begin{tabular}{|c|c|c|c|c|c|c|c|}
\hline \multirow{2}{*}{ Items $^{2}$} & \multicolumn{5}{|c|}{ Groups 1} & \multirow{2}{*}{ SEM } & \multirow{2}{*}{$p$-Value } \\
\hline & Control & $\mathrm{RSM}_{4}$ & $\mathrm{RSM}_{8}$ & $\mathrm{RSM}_{12}$ & $\mathrm{RSM}_{16}$ & & \\
\hline \multicolumn{8}{|l|}{ BW (g) } \\
\hline $35 \mathrm{~d}$ & 1978 & 1988 & 1990 & 1988 & 1980 & 4.50 & 0.93 \\
\hline $49 \mathrm{~d}$ & 3008 & 3012 & 3031 & 3030 & 3032 & 12.16 & 0.96 \\
\hline $70 \mathrm{~d}$ & 3819 & 3849 & 3894 & 3870 & 3860 & 88.86 & 0.55 \\
\hline \multicolumn{8}{|l|}{35 to $49 \mathrm{~d}$} \\
\hline $\operatorname{ADFI}(\mathrm{g} / \mathrm{d} /$ bird $)$ & 252.18 & 252.06 & 255.24 & 254.61 & 248.46 & 2.30 & 0.91 \\
\hline $\operatorname{ADG}(\mathrm{g} / \mathrm{d} / \mathrm{bird})$ & 72.10 & 73.07 & 73.38 & 74.55 & 73.46 & 0.99 & 0.97 \\
\hline $\mathrm{F} / \mathrm{G}(\mathrm{g} / \mathrm{g})$ & 3.52 & 3.46 & 3.48 & 3.43 & 3.38 & 0.03 & 0.79 \\
\hline \multicolumn{8}{|l|}{49 to $70 \mathrm{~d}$} \\
\hline $\operatorname{ADFI}(\mathrm{g} / \mathrm{d} / \mathrm{bird})$ & 256.82 & 252.74 & 261.98 & 255.66 & 258.50 & 2.60 & 0.32 \\
\hline $\operatorname{ADG}(\mathrm{g} / \mathrm{d} / \mathrm{bird})$ & 38.6 & 39.85 & 41.11 & 40.00 & 39.80 & 0.57 & 0.47 \\
\hline $\mathrm{F} / \mathrm{G}(\mathrm{g} / \mathrm{g})$ & 6.66 & 6.38 & 6.39 & 6.41 & 6.57 & 0.08 & 0.51 \\
\hline \multicolumn{8}{|l|}{35 to $70 \mathrm{~d}$} \\
\hline $\operatorname{ADFI}(\mathrm{g} / \mathrm{d} / \mathrm{bird})$ & 255.02 & 252.47 & 259.36 & 255.25 & 254.59 & 2.11 & 0.91 \\
\hline $\operatorname{ADG}(\mathrm{g} / \mathrm{d} / \mathrm{bird})$ & 52.53 & 53.14 & 54.41 & 53.82 & 53.71 & 0.48 & 0.81 \\
\hline $\mathrm{F} / \mathrm{G}(\mathrm{g} / \mathrm{g})$ & 4.86 & 4.76 & 4.77 & 4.74 & 4.74 & 0.03 & 0.84 \\
\hline
\end{tabular}

${ }^{1} \mathrm{RSM}$, rapeseed meal; $\mathrm{RSM}_{4}, \mathrm{RSM}_{8}, \mathrm{RSM}_{12}$, and $\mathrm{RSM}_{16}$ indicate that the levels of isonitrogenous replacement of soybean meal with RSM added to the diets were $4 \%, 8 \%, 12 \%$, and $16 \%$, respectively. Control group was fed a corn-soybean meal basal diet. ${ }^{2}$ Each value represents the mean of six replicate pens.

\subsection{Carcass Traits}

As shown in Table 4, different levels of dietary RSM did not affect slaughter performance of geese at $70 \mathrm{~d}$ of age, including slaughter yield, half-eviscerated carcass yield, eviscerated carcass yield, breast yield, thigh yield, or abdominal fat yield ( $p>0.05$ ).

The effect of dietary RSM on visceral development of the geese at $70 \mathrm{~d}$ is shown in Table 5. No significant difference was observed in the relative weights of heart, liver, spleen, proventriculus, or gizzard among groups $(p>0.05)$. However, the geese fed dietary $16 \%$ RSM had greater bursa of Fabricius than those of geese in the $8 \%$ group $(p<0.05)$. 
Table 4. Effects of increasing dietary levels of rapeseed meal on carcass traits of geese at $70 \mathrm{~d}$ of age (\%).

\begin{tabular}{|c|c|c|c|c|c|c|c|}
\hline \multirow{2}{*}{ Items ${ }^{2}$} & \multicolumn{5}{|c|}{ Groups 1} & \multirow{2}{*}{ SEM } & \multirow{2}{*}{$p$-Value } \\
\hline & Control & $\mathrm{RSM}_{4}$ & $\mathrm{RSM}_{8}$ & $\mathrm{RSM}_{12}$ & $\mathrm{RSM}_{16}$ & & \\
\hline Dressing percentage & 89.99 & 88.08 & 88.83 & 87.65 & 88.37 & 0.52 & 0.70 \\
\hline Half-eviscerated carcass yield & 76.37 & 74.94 & 75.84 & 74.73 & 75.24 & 0.50 & 0.81 \\
\hline Eviscerated carcass yield & 81.04 & 80.09 & 80.31 & 79.39 & 79.90 & 0.45 & 0.86 \\
\hline Breast yield & 2.50 & 2.55 & 2.54 & 2.56 & 2.59 & 0.15 & 1.00 \\
\hline Thigh yield & 4.70 & 5.02 & 5.18 & 4.82 & 5.17 & 0.52 & 0.41 \\
\hline Abdominal fat yield & 6.55 & 6.27 & 6.85 & 6.62 & 6.60 & 0.12 & 0.67 \\
\hline
\end{tabular}

${ }^{1} \mathrm{RSM}$, rapeseed meal; $\mathrm{RSM}_{4}, \mathrm{RSM}_{8}, \mathrm{RSM}_{12}$, and $\mathrm{RSM}_{16}$ indicate that the levels of isonitrogenous replacement of soybean meal with RSM added to the diets were $4 \%, 8 \%, 12 \%$, and $16 \%$, respectively. Control group was fed a corn-soybean meal basal diet. ${ }^{2}$ Each value represents the mean of six replicate pens.

Table 5. Effects of increasing dietary levels of rapeseed meal on the relative weights of visceral organs of geese at $70 \mathrm{~d}$ of age.

\begin{tabular}{|c|c|c|c|c|c|c|c|}
\hline \multirow{2}{*}{ Items $^{2}$} & \multicolumn{5}{|c|}{ Groups ${ }^{1}$} & \multirow{2}{*}{ SEM } & \multirow{2}{*}{$p$-Value } \\
\hline & Control & $\mathrm{RSM}_{4}$ & $\mathrm{RSM}_{8}$ & $\mathrm{RSM}_{12}$ & $\mathrm{RSM}_{16}$ & & \\
\hline Heart & 0.81 & 0.86 & 0.85 & 0.85 & 0.88 & 0.02 & 0.79 \\
\hline Liver & 2.43 & 2.28 & 2.15 & 2.48 & 2.35 & 0.06 & 0.46 \\
\hline Spleen & 0.13 & 0.12 & 0.10 & 0.12 & 0.13 & 0.01 & 0.84 \\
\hline Bursa of Fabricius & $0.07^{\mathrm{ab}}$ & $0.06^{\mathrm{ab}}$ & $0.05^{b}$ & $0.06^{\mathrm{ab}}$ & $0.08^{a}$ & 0.01 & 0.03 \\
\hline Gizzard & 3.72 & 3.67 & 3.87 & 3.63 & 3.54 & 0.08 & 0.76 \\
\hline Proventriculus & 0.36 & 0.35 & 0.34 & 0.35 & 0.35 & 0.01 & 0.96 \\
\hline
\end{tabular}

${ }^{a, b}$ In the same row, values with different letter superscripts mean significant difference $(p<0.05)$, while those with common or no letter superscript mean no significant difference $(p>0.05) .{ }^{1} \mathrm{RSM}$, rapeseed meal; $\mathrm{RSM}_{4}, \mathrm{RSM}_{8}, \mathrm{RSM}_{12}$, and $\mathrm{RSM}_{16}$ indicate that the levels of isonitrogenous replacement of soybean meal with RSM added to the diets were $4 \%, 8 \%, 12 \%$, and $16 \%$, respectively. Control group was fed a corn-soybean meal basal diet. ${ }^{2}$ Each value represents the mean of six replicate pens.

\subsection{Serum Biochemical and Hormonal Parameters}

The effect of dietary RSM on serum biochemical parameters of the geese at $70 \mathrm{~d}$ are shown in Table 6. Different levels of dietary RSM had no significant effect on serum concentrations of TP, ALB, GLU, TG, CHO, BUN, HDL, LDL, Ca, P, ALT, AST, or AKP ( $p>0.05)$.

Table 6. Effects of increasing dietary levels of rapeseed meal on serum biochemical parameters of geese at $70 \mathrm{~d}$ of age ${ }^{1}$.

\begin{tabular}{|c|c|c|c|c|c|c|c|}
\hline \multirow{2}{*}{ Items $^{3}$} & \multicolumn{5}{|c|}{ Groups $^{2}$} & \multirow{2}{*}{ SEM } & \multirow{2}{*}{$p$-Value } \\
\hline & Control & $\mathbf{R S M}_{4}$ & $\mathrm{RSM}_{8}$ & $\mathrm{RSM}_{12}$ & $\mathrm{RSM}_{16}$ & & \\
\hline $\mathrm{TP}(\mathrm{g} / \mathrm{L})$ & 57.85 & 61.97 & 58.50 & 64.13 & 58.93 & 1.40 & 0.60 \\
\hline $\operatorname{ALB}(\mathrm{g} / \mathrm{L})$ & 24.70 & 26.00 & 24.26 & 24.48 & 24.70 & 0.37 & 0.63 \\
\hline GLU (mmol/L) & 13.11 & 13.04 & 13.23 & 13.03 & 14.10 & 0.28 & 0.76 \\
\hline BUN (mmol/L) & 0.93 & 0.99 & 0.89 & 0.87 & 0.76 & 0.04 & 0.47 \\
\hline TG (mmol/L) & 0.65 & 0.79 & 0.69 & 0.67 & 0.63 & 0.03 & 0.66 \\
\hline $\mathrm{CHO}(\mathrm{mmol} / \mathrm{L})$ & 7.54 & 8.15 & 7.61 & 7.86 & 8.29 & 0.21 & 0.76 \\
\hline LDL (mmol/L) & 2.57 & 2.82 & 2.71 & 2.91 & 2.74 & 0.09 & 0.87 \\
\hline HDL (mmol/L) & 3.78 & 3.95 & 3.76 & 3.71 & 4.34 & 0.09 & 0.22 \\
\hline $\mathrm{P}(\mathrm{mmol} / \mathrm{L})$ & 3.67 & 3.97 & 3.58 & 4.02 & 3.40 & 0.09 & 0.22 \\
\hline $\mathrm{Ca}(\mathrm{mmol} / \mathrm{L})$ & 4.88 & 5.21 & 4.86 & 5.04 & 4.61 & 0.08 & 0.18 \\
\hline ALT (U/L) & 25.78 & 29.90 & 26.00 & 24.05 & 22.53 & 1.15 & 0.33 \\
\hline AST (U/L) & 118.5 & 105.4 & 116.9 & 99.19 & 99.62 & 7.40 & 0.88 \\
\hline AKP (U/L) & 1512 & 1697 & 1704 & 1527 & 1447 & 56.34 & 0.52 \\
\hline
\end{tabular}

${ }^{1}$ Each value represents the mean of six replicate pens. ${ }^{2}$ RSM, rapeseed meal; $\mathrm{RSM}_{4}, \mathrm{RSM}_{8}, \mathrm{RSM}_{12}$, and RSM 16 indicate that the levels of isonitrogenous replacement of soybean meal with RSM added to the diets were $4 \%, 8 \%, 12 \%$, and $16 \%$, respectively. Control group was fed a corn-soybean meal basal diet. ${ }^{3} \mathrm{TP}$, total protein; ALB, albumin; GLU, glucose; BUN, blood urea nitrogen; TG, triglyceride; CHO, cholesterol; LDL, low-density lipoprotein; HDL, high-density lipoprotein; P, phosphorus; Ca, calcium; ALT, alanine aminotransferase; AST, aspartate aminotransferase; $\mathrm{AKP}$, alkaline phosphatase. 
The serum hormonal parameters of geese at $70 \mathrm{~d}$ are shown in Table $7(p>0.05)$. The serum concentration of GH significantly increased when geese were fed $12 \%$ and $16 \%$ dietary RSM $(p<0.05)$. The serum concentration of T3 of geese fed $8 \%$ dietary RSM slightly increased compared with groups $4 \%(p=0.051)$. Serum TSH and T4 were unaffected by dietary $\operatorname{RSM}(p>0.05)$.

Table 7. Effects of increasing dietary levels of rapeseed meal on serum hormonal parameters of geese at $70 \mathrm{~d}$ of age ${ }^{1}$.

\begin{tabular}{|c|c|c|c|c|c|c|c|}
\hline \multirow{2}{*}{ Items $^{3}$} & \multicolumn{5}{|c|}{ Groups $^{2}$} & \multirow{2}{*}{ SEM } & \multirow{2}{*}{$p$-Value } \\
\hline & Control & $\mathrm{RSM}_{4}$ & $\mathbf{R S M}_{8}$ & $\mathrm{RSM}_{12}$ & $\mathbf{R S M}_{16}$ & & \\
\hline GH (ng/mL) & $8.92^{\mathrm{A}}$ & $9.34^{\mathrm{A}}$ & $10.22^{\mathrm{A}}$ & $13.66^{\mathrm{B}}$ & $12.46^{\mathrm{B}}$ & 0.42 & $<0.01$ \\
\hline TSH (mU/L) & 27.25 & 33.53 & 29.04 & 25.98 & 27.18 & 1.11 & 0.27 \\
\hline T3 (nmol/L) & $5.19^{a b}$ & $5.00^{b}$ & $6.21^{a}$ & $5.89^{a b}$ & $5.88^{a b}$ & 0.15 & 0.05 \\
\hline T4 (nmol/L) & 137.8 & 144.4 & 138.9 & 153.1 & 162.9 & 5.12 & 0.49 \\
\hline
\end{tabular}

A,B Means with different superscripts within the same row differ significantly $(p<0.01)$. ${ }^{a, b} 0.05 \leq p<0.10$ was considered to be a tendency towards significant. ${ }^{1}$ Each value represents the mean of six replicate pens. ${ }^{2}$ RSM, rapeseed meal; RSM $, \mathrm{RSM}_{8}, \mathrm{RSM}_{12}$, and RSM 16 indicate that the levels of isonitrogenous replacement of soybean meal with RSM added to the diets were $4 \%$, $8 \%, 12 \%$, and $16 \%$, respectively. Control group was fed a corn-soybean meal basal diet. ${ }^{3} \mathrm{GH}$, growth hormone; TSH, thyroid-stimulating hormone; T3, triiodothyronine; T4, tetraiodothyronine.

\subsection{Intestinal Development}

The relative weight and morphological measurements of the small intestine in geese are presented in Table 8. Dietary RSM up to $16 \%$ had no effect on the relative weight of duodenum, jejunum, and ileum $(p>0.05)$. Dietary RSM of $12 \%$ and more slightly decreased the crypt depth of duodenum $(p=0.06)$, whereas no difference was found in villus height among groups $(p>0.05)$. No effects of dietary RSM were observed on the crypt depth or the villus height of the jejunum or ileum $(p>0.05)$.

Table 8. Effects of increasing dietary levels of rapeseed meal on relative weight, villus height $(\mu \mathrm{m})$ and crypt depth ( $\mu \mathrm{m})$ of geese at $70 \mathrm{~d}$ of age ${ }^{1}$.

\begin{tabular}{|c|c|c|c|c|c|c|c|}
\hline \multirow{2}{*}{ Items $^{2}$} & \multicolumn{5}{|c|}{ Groups ${ }^{1}$} & \multirow{2}{*}{ SEM } & \multirow{2}{*}{$p$-Value } \\
\hline & Control & $\mathrm{RSM}_{4}$ & $\mathrm{RSM}_{8}$ & $\mathrm{RSM}_{12}$ & $\mathrm{RSM}_{16}$ & & \\
\hline \multicolumn{8}{|l|}{ Duodenum } \\
\hline $\begin{array}{c}\text { Relative } \\
\text { weight }\end{array}$ & 2.18 & 2.14 & 2.15 & 2.23 & 2.18 & 0.06 & 0.99 \\
\hline Villus height & 1252 & 1215 & 1248 & 1162 & 1358 & 33.01 & 0.45 \\
\hline $\begin{array}{l}\text { Crypt depth } \\
\text { Jejunum }\end{array}$ & $298.3^{a}$ & $299.1^{a}$ & $297.4^{\mathrm{a}}$ & $229.7^{b}$ & $233.5^{b}$ & 11.20 & 0.06 \\
\hline $\begin{array}{c}\text { Relative } \\
\text { weight }\end{array}$ & 4.74 & 4.19 & 4.35 & 4.17 & 4.67 & 0.11 & 0.40 \\
\hline Villus height & 1363 & 1365 & 1524 & 1296 & 1483 & 43.72 & 0.47 \\
\hline $\begin{array}{l}\text { Crypt depth } \\
\text { Ileum }\end{array}$ & 268.4 & 299.4 & 244.4 & 235.2 & 299.7 & 12.55 & 0.35 \\
\hline $\begin{array}{c}\text { Relative } \\
\text { weight }\end{array}$ & 4.19 & 3.87 & 4.07 & 4.11 & 3.80 & 0.13 & 0.87 \\
\hline Villus height & 1014 & 874.2 & 883.3 & 1009 & 783.8 & 39.20 & 0.29 \\
\hline Crypt depth & 253.9 & 245.7 & 245.5 & 218.3 & 228.5 & 9.61 & 0.79 \\
\hline
\end{tabular}

a,b $0.05 \leq p<0.10$ was considered to be a tendency towards significant. ${ }^{1}$ Each value represents the mean of six replicate pens. ${ }^{2}$ RSM, rapeseed meal; $\mathrm{RSM}_{4}, \mathrm{RSM}_{8}, \mathrm{RSM}_{12}$, and $\mathrm{RSM}_{16}$ indicate that the levels of isonitrogenous replacement of soybean meal with RSM added to the diets were $4 \%, 8 \%, 12 \%$, and $16 \%$, respectively. Control group was fed a corn-soybean meal basal diet.

\section{Discussion}

\subsection{Chemical Composition of Rapeseed Meal}

The glucosinolate concentration in the rapeseed meal used in the current study, confirmed the standard of low-glucosinolate RSM (GLS $\leq 45 \mu \mathrm{mol} / \mathrm{g}$ ) promulgated by the Ministry of Agriculture of China. The content of CP, CF, ash, Ca, TP, Met, and Lys agreed 
well with the data in Tables of Feed Composition and Nutritive Values in China [20]. Compared with SBM, RSM contained less CP (36.73\% vs. 43.01\%), and Lys (1.63\% vs. 2.66\%), but more CF (9.48\% vs. $6.48 \%$ ) and Met (0.71\% vs. $0.58 \%)$. Therefore, the RSM selected was representative and usability.

\subsection{Growth Performance}

During the entire experiment trial, no geese exhibited clinical symptoms such as diarrhea, leg abnormalities, or sudden death due to low-glucosinolate RSM treatment. Although these adverse reactions caused by excessive GLS are likely to occur in chickens $[6,21]$, they have not been pronouncedly reported in geese yet. Further study was significantly needed on the toxicity of GLS on geese. However, it was reported that chickens could positively respond to dietary double-low RSM (e.g., Canola, up to 20\%) and grow without abnormal symptoms [11]. In view of the fact that the current RSM variety contains low GLS, the pathogenic impact tends to be minor [14].

Previous research reported that dietary RSM from $15 \%$ to $20 \%$ had no negative effect on broiler performance $[8,15,22,23]$. The current study also indicates that dietary RSM could maintain the growth performance of geese over short-term feeding. However, some other studies [11,24] found that adding $15 \%$ or $20 \%$ RSM to diets reduced weight gain and increased F/G of broilers. In view of different feeding designs, the discrepancy in growth depression may partly depend on feed factors including RSM varieties, processing, and diets formulation, determining the dietary GLS and ANFs contents $[25,26]$.

Additionally, Zhu et al. [3] demonstrated that the BW gain of Cherry Valley ducks decreased linearly as the dietary RSM increased from $5 \%$ to $20 \%$ (7 to $14 \mathrm{~d}$ of age) growth rate was not affected from 15 to $21 \mathrm{~d}$. Mikulski et al. [16] observed that turkeys receiving dietary RSM up to $18 \%$ had an increased F/G during a long feeding period of $147 \mathrm{~d}$. In the current study, the development of the digestive tract of 35 to 70-d-old geese was improved after a brooding period of $28 \mathrm{~d}$. As raised for a comparatively shorter period than turkeys, the negative reaction of geese growth to dietary RSM and its ANFs might be smaller than that in the starter period. The current results likely indicate a low hypotoxicity of the selected RSM variety and distinct adaptability of geese to graded levels of dietary RSM. In view of the positive feeding response, rapeseed meal is a suitable protein substitute for SBM in geese diets.

\subsection{Carcass Traits}

Carcass characteristic is one of the most crucial indicators of growth performance and saleability of meat poultry [2]. The reported effects of RSM on carcass yield of poultry were not consistent in recent studies. Mikulski et al. [16] observed that dietary RSM from 6\% to $18 \%$ had no effect on dressing percentage, breast and thigh yield, and the abdominal fat pad of turkeys, as is similar to the current study. Moreover, in broilers feeding, it was generally suggested that diets containing $20 \%$ of low-glucosinolate RSM did not affect carcass and breast yields negatively $[15,23]$. In addition, the abdominal fat pad decreased linearly when dietary RSM increased from 4\% to 16\% [27]. However, Taraz et al. [28] observed that the replacement of high-glucosinolate RSM (79 $\mu \mathrm{mol} / \mathrm{g}$ RSM) with SBM at a level greater than $7.5 \%$ in diet reduced carcass weight and the abdominal fat pad of broiler chicks, as the feed intake decreased followed by a poor growth rate. For other crop byproducts, Yu et al. [2] reported that replacing low-gossypol cottonseed meal for dietary SBM could maintain the carcass yield of geese. Following Yu et al., the current result may suggest that geese fed low-glucosinolate RSM-contained diets can achieve slaughter performance as well as those fed corn-SBM-contained diets.

The relative weight of visceral organs is a key indicator of organ health and physical functions. The toxicity of RSM may stunt the organogenetic development of animals [7]. Supported by serum AKP, ALT, and AST, however, the current result was agreed with Qin et al. [9], who found no visible changes on the liver of ducklings fed RSM up to 30\% for 21d. Although Zhu et al. [3] observed liver enlargement of ducks receiving 5\% to 
$20 \%$ dietary RSM with 1.37 to $5.31 \mu \mathrm{mol}$ GLS/g diet, it was argued that a short period of feeding double-low RSM was insufficient to induce severe liver damage. In contrast, long-term feeding of dietary RSM causes organic changes by ingested GLS and promotes gizzard enlargement by its high content of crude fiber and NSP $[6,15,16]$. In the current study, however, all diets provided equal amounts of dietary fibers. Moreover, geese have developed gizzards which lead to high endurance to dietary fibers [29]. This can explain why the current gizzards similarly weighed at the end of the feeding period. As inconsistent with Zhu's et al. [3] study, however, the enlarged bursa of Fabricius (BF) manifests that the geese could exhibit an immune reaction to high dietary RSM even under low ingestion of GLS $(<1.97 \mu \mathrm{mol}$ GLS/g diet). Nutritional research suggested that the enlargement of immune organs commonly represents a positive immune response to feed ingredients or dietary nutrients, which indicated that immune function was enhanced [30]. However, the visible enlargement accompanied by pathological damage could also be found in immune organs (e.g., spleen) when poultry was impacted by pathogenic factors [31]. Although no distinctive lesion was observed on the $\mathrm{BF}$, the current data are not sufficient to prove the correlation between the BF ratio and immune status. To sum up, short-term use of low-glucosinolate RSM presents no impairment to circulatory and alimentary organ health and functions of geese.

\subsection{Serum Biochemical and Hormonal Parameters}

Serum parameters reflect the metabolism of nutrients and physiological status in the body regarding growth and development. Serum biochemical parameters indicate that dietary RSM did not affect the metabolism of proteins, lipids, and minerals, which supported the current growth performance. It was well-acknowledged that $\mathrm{GH}$ is an important factor in body growth and metabolism. However, research on chickens [32] showed that serum GH was not simply positively correlated with growth performance. A 35-d RSM feeding did not increase or decrease the growth rate of geese. As there was no research to prove the correlation between dietary RSM and GH, further study would be needed.

Dietary GLS has been shown to suppress the synthesis of thyroid hormone then cause the pituitary to release TSH, which induce thyroid follicular hyperplasia and goiter. However, an elevation of serum triiodothyronine even occurred through feeding RSM. The same result was also achieved by Qiao and Classen [33] that solvent-extracted canola meal increased serum triiodothyronine levels in the broiler. Moreover, Woyengo et al. [13] and Zhu et al. [3] found no difference in serum thyroid hormone of broilers or ducks, respectively. Although the mechanism of increasing serum triiodothyronine by dietary RSM is still unclear, the current result can at least show that geese fed low-GLS RSM for $35 \mathrm{~d}$ can maintain the normal endocrine function of the thyroid gland.

\subsection{Intestinal Development}

Intestinal morphological structure partly determines the nutrient digestion and absorption in geese. Dietary RSM could influence growth performance by altering intestinal morphology [34]. As reported by Gopinger et al. [8], the results obtained showed a tendency of a linear reduction of crypt depth of duodenum with the inclusion of canola meal in the diet, which is similar to the current findings. Higher villus height and shallower crypt depth commonly indicate highly mature cells and greater secretory ability [35]. Though the morphological observation aligns with geese performance, the potential effect of RSM on intestinal development needs further evaluation.

\section{Conclusions}

During a $35-\mathrm{d}$ feeding, a dietary rapeseed meal from $4 \%$ to $16 \%$ had no obvious effect on the growth performance, carcass traits, and intestinal development of geese from 35 to $70 \mathrm{~d}$ of age. We recommend that rapeseed meal can be used up to $16 \%$ in the geese diet from 35 to $70 \mathrm{~d}$ of age for saving feed cost. 
Author Contributions: Literature search, figures, study design, data analysis, data interpretation, writing, review, Z.F. Data collection, G.S., Q.S., T.Z. Study design, Z.F., H.Y., Z.W. Fund support, H.Y., Z.W. All authors have read and agreed to the published version of the manuscript.

Funding: This work was financially supported by the Project of the China Agriculture Research System (CARS-42-11) and the Jiangsu Agriculture Science and Technology Innovation Fund (CX (18)1004).

Institutional Review Board Statement: The Yangzhou University Animal Care and Use Committee approved all bird-handling protocols used in the study, with permit number SYXK (Su) IACUC 2012-0029.

Data Availability Statement: No other data reported.

Conflicts of Interest: The authors declare no conflict of interest.

\section{References}

1. Chen, X.S.; Yang, H.M.; Wang, Z.Y. The effect of different dietary levels of defatted rice bran on growth performance, slaughter performance, serum biochemical parameters, and relative weights of the viscera in geese. Animals 2019, 9, 1040. [CrossRef]

2. Yu, J.; Yang, H.M.; Wan, X.L.; Chen, Y.J.; Yang, Z.; Liu, W.F.; Liang, Y.Q.; Wang, Z.Y. Effects of cottonseed meal on slaughter performance, meat quality, and meat chemical composition in Jiangnan White goslings. Poult. Sci. 2020, 99, 207-213. [CrossRef]

3. Zhu, Y.W.; Yang, W.C.; Liu, W.; Yin, X.H.; Yang, L. Effects of dietary rapeseed meal inclusion levels on growth performance, organ weight, and serum biochemical parameters in Cherry Valley ducks. Poult. Sci. 2019, 98, 6888-6896. [CrossRef] [PubMed]

4. Wickramasuriya, S.; Yi, Y.J.; Yoo, J.; Kang, N.K.; Heo, J.M. A review of canola meal as an alternative feed ingredient for ducks. J. Anim. Sci. Technol. 2015, 57, 29. [CrossRef] [PubMed]

5. Chen, X.; Parr, C.; Utterback, P.; Parsons, C.M. Nutritional evaluation of canola meals produced from new varieties of canola seeds for poultry. Poult. Sci. 2015, 94, 984-991. [CrossRef] [PubMed]

6. Tripathi, M.K.; Mishra, A.S. Glucosinolates in animal nutrition: A review. Anim. Feed Sci. Tech. 2007, 132, 1-27. [CrossRef]

7. Mawson, R.; Heaney, R.K.; Zdunczyk, Z.; Kozlowska, H. Rapeseed meal-glucosinolates and their antinutritional effects Part 4. Goitrogenicity and internal organs abnormalities in animals. Mol. Nutr. Food Res. 1994, 38, 178-191. [CrossRef]

8. Gopinger, E.; Xavier, E.G.; Elias, M.C.; Catalan, A.A.S.; Castro, M.L.S.; Nunes, A.P.; Roll, V.F.B. The effect of different dietary levels of canola meal on growth performance, nutrient digestibility, and gut morphology of broiler chickens. Poult. Sci. 2014, 93, 1130-1136. [CrossRef]

9. Qin, S.; Tian, G.; Zhang, K.; Ding, X.; Bai, S.; Wang, J.; Jia, G.; Zeng, Q. Influence of dietary rapeseed meal levels on growth performance, organ health and standardized ileal amino acid digestibility in meat ducks from 15 to 35 days of age. J. Anim. Physiol. Anim. Nutr. 2017, 101, 1297-1306. [CrossRef]

10. Mawson, R.; Heaney, R.K.; Zdunczyk, Z.; Kozlowska, H. Rapeseed meal-glucosinolates and their antinutritional effects Part II. Flavour and palatability. Mol. Nutr. Food Res. 1993, 37, 336-344. [CrossRef]

11. Olukosi, O.A.; Kasprzak, M.M.; Kightley, S.; Carre, P.; Houdijk, J.G.M. Investigations of the nutritive value of meals of double-low rapeseed and its influence on growth performance of broiler chickens. Poult. Sci. 2017, 96, 3338-3350. [CrossRef]

12. McNeill, L.; Bernard, K.; MacLeod, M.G. Food intake, growth rate, food conversion and food choice in broilers fed on diets high in rapeseed meal and pea meal with observations of the resulting poultry meat. Br. Poult. Sci. 2004, 45, 519-523. [CrossRef] [PubMed]

13. Woyengo, T.A.; Kiarie, E.; Nyachoti, C.M. Growth performance, organ weights, and blood parameters of broilers fed diets containing expeller-extracted canola meal. Poult. Sci. 2011, 90, 2520-2527. [CrossRef] [PubMed]

14. Aljuobori, A.; Zulkifli, I.; Soleimani, A.F.; Abdullah, N.; Liang, J.B.; Mujahid, A. Higher inclusion rate of canola meal under high ambient temperature for broiler chickens. Poult. Sci. 2016, 95, 1326-1331. [CrossRef] [PubMed]

15. Ahmad, G.; Mushtaq, T.; Mirza, M.A.; Ahmed, Z. Comparative bio-efficacy of lysine from L-lysine hydrochloride or L-lysine sulfate in basal diets containing graded levels of canola meal for female broiler chickens. Poult. Sci. 2007, 86, 525-530. [CrossRef]

16. Mikulski, D.; Jankowski, J.; Zdunczyk, Z.; Juskiewicz, J.; Slominski, B.A. The effect of different dietary levels of rapeseedmeal on growth performance, carcass traits, and meat quality in turkeys. Poult. Sci. 2012, 91, 215-223. [CrossRef]

17. Lu, J.; Kong, X.L.; Wang, Z.Y.; Yang, H.M.; Zhang, K.N.; Zou, J.M. Influence of whole corn feeding on the performance, digestive tract development, and nutrient retention of geese. Poult. Sci. 2011, 90, 587-594. [CrossRef]

18. NRC. Nutrient Requirements of Poultry, 9th ed.; National Academy Press: Washington, DC, USA, 1994.

19. AOAC. Official Methods of Analysis, 18th ed.; AOAC Int.: Arlington, VA, USA, 2006.

20. Feed Database in China. Table of Feed Composition and Nutritive Value in China, 25th ed.; China Intercontinental Press: Bejing, China, 2014.

21. Campbell, L.D.; Smith, T.K. Response of growing chicks to high dietary content of rapeseed meal. Br. Poult. Sci. 1979, 20, 231-237. [CrossRef]

22. Maroufyan, E.; Kermanshahi, H. Effect of different levels of rapeseed meal supplemented with calcium iodate on performance, some carcass traits, and thyroid hormones of broiler chickens. Int. J. Poult. Sci. 2006, 5, 1073-1078. 
23. Mushtaq, T.; Sarwar, M.; Ahmad, G.; Mirza, M.A.; Nawaz, H.; Mushtaq, M.M.H.; Noreen, U. Influence of canola meal-based diets supplemented with exogenous enzyme and digestible lysine on performance, digestibility, carcass, and immunity responses of broiler chicken. Poult. Sci. 2007, 86, 2144-2151. [CrossRef]

24. Zeb, A.; Sattar, A.; Shah, A.B.; Bibi, B.; Meulen, U.T. Effects of feeding increased levels of heat processed rapeseed meal on performance of broiler chicks. Arch. Geflügelk. 2002, 66, 158-163.

25. Doranalli, K.; Helmbrecht, A.; Payne, R.L. Effect of heat treatment of rapeseed meal on performance and carcass characteristics of broiler chickens. In Proceedings of the 24th Annual Australian Poultry Science Symposium, Sydney, Australia, 17-20 February 2013; pp. 163-166.

26. Ullah, Z.; Rehman, Z.U.; Yin, Y.; Stein, H.H.; Sarwar, M. Comparative ileal digestibility of amino acids in 00-rapeseed meal and rapeseed meal fed to growing male broilers. Poult. Sci. 2017, 96, 2736-2742. [CrossRef] [PubMed]

27. Montazer-Sadegh, R.; Ebrahim-Nezhad, Y.; Maberi-Sis, N. Replacement of different levels of rapeseed meal with soybean meal on broilers performance. Asian J. Anim. Vet. Adv. 2008, 3, 278-285. [CrossRef]

28. Taraz, Z.; Jalali, S.; Rafeie, F. Effects of replacement of soybean meal with rapeseed meal on organs weight some blood biochemical parameters and performance of broiler chicks. Int. J. Poult. Sci. 2006, 5, 1110-1115.

29. Li, Y.P.; Wang, Z.Y.; Yang, H.M.; Xu, L.; Xie, Y.J.; Jin, S.L.; Sheng, D.F. Effects of dietary fiber on growth performance, slaughter performance, serum biochemical parameters, and nutrient utilization in geese. Poult. Sci. 2017, 96, 1250-1256. [CrossRef] [PubMed]

30. Miao, Z.G.; Zhao, W.X.; Guo, L.P.; Wang, S.; Zhang, J.Z. Effects of dietary supplementation of chitosan on immune function in growing Huoyan geese. Poult. Sci. 2020, 99, 95-100. [CrossRef]

31. Liu, Q.; Zhang, G.; Huang, Y.; Ren, G.; Su, J. Isolation and characterization of a reovirus causing spleen necrosis in pekin ducklings. Vet. Microbiol. 2011, 148, 200-206. [CrossRef]

32. Reiprich, K.; Mühlbauer, E.; Decuypere, E.; Grossmann, R. Characterization of growth hormone gene expression in the pituitary and plasma growth hormone concentrations during posthatch development in the chicken. J. Endocrinol. 1995, 145, 343-353. [CrossRef]

33. Qiao, H.Y.; Classen, H.L. Nutritional and physiological effects of rapeseed meal sinapine in broiler chickens and its metabolism in the digestive tract. J. Sci. Food Agric. 2003, 83, 1430-1438. [CrossRef]

34. Figueiredo, D.F.; Murakami, A.; Pereira, M.; Furlan, A.; Toral, F. Desempenho e morfometria da mucosa de duodeno de frangos de corte alimentados com farelo de canola, durante o período inicial. R. Bras. Zootec. 2003, 32, 1321-1329. [CrossRef]

35. Wan, Y.; Ma, R.; Khalid, A.; Chai, L.; Zhan, K. Effect of the pellet and mash feed forms on the productive performance, egg quality, nutrient metabolism, and intestinal morphology of two laying hen breeds. Animals 2021, 11, 701. [CrossRef] [PubMed] 